Summer 2010

\title{
A Review of Making People Illegal: What Globalization Means for Migration and Law, by Catherine Dauvergne
}

Andy Williams

Indiana University Maurer School of Law

Follow this and additional works at: https://www.repository.law.indiana.edu/ijgls

Part of the Immigration Law Commons, and the International Law Commons

\section{Recommended Citation}

Williams, Andy (2010) "A Review of Making People Illegal: What Globalization Means for Migration and Law, by Catherine Dauvergne," Indiana Journal of Global Legal Studies: Vol. 17 : Iss. 2 , Article 13. Available at: https://www.repository.law.indiana.edu/ijgls/vol17/iss2/13

This Book Review is brought to you for free and open access by the Law School Journals at Digital Repository @ Maurer Law. It has been accepted for inclusion in Indiana Journal of Global Legal Studies by an authorized editor of Digital Repository @ Maurer Law. For more information, please contact rvaughan@indiana.edu. 


\title{
A Review of Making People Illegal: What Globalization Means for Migration and Law by Catherine Dauvergne
}

\begin{abstract}
ANDY WILLIAMS ${ }^{*}$
Catherine Dauvergne's book, Making People Illegal: What Globalization Means for Migration and Law, is a study of the intersection between the phenomenon known as globalization and the evolution of migration law. Dauvergne's central assertion is that migration law, accompanied by what she sees as the recent global crackdown on illegal migration, has become the "last bastion of sovereignty" for the nation-state in the face of the advancing forces of globalization. ' Dauvergne argues that, as more of the policy decisions that traditionally fall in the domain of national sovereign power enter the murky realm of globalization, nation-states have increasingly turned to their domestic migration laws as a way to shore up their borders-both physical and intangible-and thus to reassert their national identities. ${ }^{2}$ This reassertion of nation-states' weakening sovereignty serves as a barrier to meaningful progress in fighting illegal migration because it "contributes to failures of policy, law, and imagination" by discouraging creative proposals that seek to detach migration policy from domestic legal frameworks. ${ }^{3}$ Where Dauvergne's book remains focused on developing this argument, it is compelling, original, persuasive, and generally successful.

The book focuses on a diverse range of topics, including labor migration, refugee law, human trafficking and smuggling, national security, and the nature of citizenship. ${ }^{4}$ She makes clear at the outset that her book is not confined to any one of these topics; rather, it is

* Associate Editor, Indiana Journal of Global Legal Studies; J.D. Candidate, 2011, Indiana University Maurer School of Law; B.A., 2008, DePauw University.

1. Catherine Dauvergne, Making People Illegal: What Globalization Means FOR MIGRATION AND LAW 2 (2008).

2. See id. at 17 .

3. Id. at 170 .

4. Id. at 3 .
\end{abstract}

Indiana Journal of Global Legal Studies Vol. 17 \#2 (Summer 2010)

(C) Indiana University Maurer School of Law

DOI: 10.2979/GLS.2010.17.2.413 
meant to "select sample instances for analysis that offer original insights regarding each of these areas." Dauvergne refers to this strategy as "core sampling," an analogy to the methodology used by ice scientists. ${ }^{6}$ Dauvergne's core samples serve as focal points for each of her chapters, and range from international events to agency reports. For each of her focus areas, Dauvergne chooses a core sample of current significance and uses it to tell the broader story of illegal immigration and globalization. In her introduction, she accurately observes that "[t]he persuasive effects of these choices will be one of the crucial ways to assess this book."

In this review, I will examine this structure and whether Dauvergne's examples have the power to persuade. After a discussion of Dauvergne's foundational chapters, in which she examines the importance of modern terminology as applied to migration and migrants and migration's significance in the larger framework of globalization, I turn to her five core sampling chapters. In discussing each chapter, I identify the specific sample on which Dauvergne focuses, followed by an analysis of the effectiveness of her arguments. Finally, I conclude with a broader perspective on the success of her strategy as a whole.

Before she begins her project of core sampling, Dauvergne examines the term "illegal" as it is applied to people in the context of migration. The chapter "On Being Illegal" begins with the argument that, because being an illegal migrant is a status imposed by a legal framework, the only way to truly eliminate the problem of illegal migration would be to repeal all laws meant to regulate it. ${ }^{8}$ Although this suggestion will be seen by most as wildly unrealistic, it is effective in making Dauvergne's point that the term illegal, when used to describe a group of people, is a procedural term meant to carry with it a whole host of substantive assumptions. Within the rhetoric of the global crackdown on illegal migration, those known as illegal are contained within the stereotype of the "poor, brown, and destitute." Dauvergne sees this label as essential to the reassertion of individual national sovereignty. When physical borders fail, she argues, states exclude undesirable people from within by labeling them illegal-thus robbing them of the rights and privileges belonging to legitimate members of the society. ${ }^{10}$ Hence, the state retains control of its national identity even when it fails to physically

\footnotetext{
5. Id.

6. Id.

7. Id.

8. See id. at 15.

9. Id. at 16 .

10. Id. at 17; see also id. at 22 (describing how "[r]ights talk in the absence of other forms of privilege is often just that: talk").
} 
exclude "outsiders." 11

Dauvergne successfully invokes a real sense of moral alarm as she presents her argument in this section. Her observations regarding the stereotypes conjured by the term illegal evoke memories of recent media tirades on the subject of illegal immigration, and her analysis of the practice of exclusion from within is difficult to rebut. In short, the persuasive power of this chapter provides a solid foundation for the rest of the book.

Dauvergne turns next to a brief overview of migration as it fits into the larger phenomenon of globalization. She first recognizes the fluid and imprecise nature of globalization and conceptualizes globalization as a process of breaking down nation-state sovereignty by the application of global pressures-usually economic-that exist outside the control of most individual nations. ${ }^{12}$ One way that nation-states respond to these pressures, according to Dauvergne, is to use migration law as a renationalizing force, rallying their citizens with antiimmigrant rhetoric. ${ }^{13}$ Essential to Dauvergne's larger thesis are her assertions that a nation is composed of and defined by its citizens and that control over the composition of the citizenry is control over national identity. ${ }^{14}$ Dauvergne argues, therefore, that by breaching the borders illegal migrants are attacking the heart of the nation-state's sovereign power. ${ }^{15}$ This makes migration law the logical tool with which states resist the pressures of a globalizing world.

Dauvergne supports her argument regarding the motivations of nation-states in crafting their migration laws with solid logic and accurate observations, making her controversial conclusion appear nearly unavoidable. Once the reader accepts her claim that a nation's identity is its citizens, it is a short step to view an influx of unsanctioned migrants as a direct assault on the perceived sovereignty of the nation-state. And if the reader also accepts the premise that prosperous Western nations intend to reassert their waning sovereignty in the face of globalizing forces, the proposition that strengthened enforcement of domestic migration laws could serve as the front line of this struggle becomes quite reasonable. The persuasive power of her opening chapters lays the groundwork for Dauvergne to begin her project of core sampling.

11. See id. at 17 (arguing that "[w]hen the nation is unable to assert its traditional sovereignty by closing its borders, it retains the power to separate 'us' from 'them' through this labeling [of illegall').

12. See id. at $29-32$.

13. Id. at 43 .

14. Id. at 45 .

15. See id. at 48 . 
The first core sampling chapter, entitled "Making Asylum Illegal," addresses the issue of refugee law as a constraint on state sovereignty and the recent retreat by prosperous Western nation-states from the substance of the 1951 Convention Relating to the Status of Refugees. ${ }^{16}$ Dauvergne's core sample in this chapter is the story of the MV Tampa, a Norwegian container ship that in the summer of 2001 rescued over four hundred Afghan refugees off the coast of Australia. The Australian government's refusal to allow the asylum-seekers to come ashore, and the resulting standoff, led Australia to adopt a number of provisions limiting the reach of refugee and asylum law. For Dauvergne, these actions represent a larger trend by Western nations to adopt more inflexible and restrictive interpretations of the requirements of the Refugee Convention. ${ }^{17}$

While Dauvergne acknowledges that "much of the story of making asylum illegal is dark indeed," she finds some encouragement in the way Western courts are responding to human rights arguments regarding refugee and asylum claims in the wake of increased governmental restriction of refugee rights. ${ }^{18}$ The fact that many such successful human rights-based assertions have been made in Western courts suggests to Dauvergne that these courts are drawing upon a concept of the rule of law that extends beyond the borders of their respective nation-states. ${ }^{19}$ If Dauvergne's observation is correct, it would be a hopeful sign for supporters of a strengthened Refugee Convention interpretation, given the profound respect many Western nations have for the concept of the rule of law as a foundation for democracy. For this reason, Dauvergne sees refugee law as presently the best remedy available (though by no means a sufficient one) for the growing problem of illegal migration. ${ }^{20}$

Dauvergne next turns her focus to human trafficking and, specifically, the roles that gender and victimization play in shaping Western responses to this practice. ${ }^{21}$ The core sample at issue in this section is the U:S. State Department's annual Trafficking in Persons (TIP) Report-especially the photographs that accompany each edition of the report. ${ }^{22}$ She begins with some general observations about victimization and trafficking and argues that identifying victims helps to cast trafficking as a crime and makes it harder for nation-states to

\footnotetext{
16. Id. at $50-54$.

17. Id. at 51 .

18. Id. at 67-68.

19. Id. at 67.

20. Id. at 170 .

21. Id. at 73-74.

22. Id.
} 
label the victims of trafficking as illegal. ${ }^{23}$ Dauvergne posits that the recent global crackdown on illegal migration and the attempts by nation-states to reassert sovereignty over their borders have improved the market for human trafficking by providing increased incentives for its victims (a majority of whom are young women engaged in the sex trade) to consent to the trafficking. She makes it clear, however, that the issue of consent is a complicated one enhanced by the idea of victimization. ${ }^{24}$ For these reasons, the United States' leadership role in addressing human trafficking, particularly the way in which the U.S. State Department's report presents the issue, deserves closer examination.

The TIP Report is an annual report issued by the U.S. State Department that details the problem of human trafficking and displays victim profiles and photographs. Dauvergne's interest in these photographs centers on their authenticity and rhetorical effect. ${ }^{25}$ The photographs are a mixture of "true" pictures of actual victims and posed pictures meant to be representative of "typical" situations in the trafficking market. ${ }^{26}$ Dauvergne's analysis covers a dizzying array of ethical issues raised by the use of the photographs, including the tendency for the pictures to focus attention on the role of the victims as helpless, the ambiguity of the message that uncaptioned photos advance, the potential invasion of privacy perpetrated by the "true" photos, and the emotional power of the photos as a whole. ${ }^{27}$ The effect of this analysis, while fascinating and insightful, is to obscure Dauvergne's broader point about the role of gender and victimization in the United States' hegemonic response to human trafficking. The complexity of the issues presented by the photographs and the difficulty in reaching any conclusion about the propriety of their use outweigh the persuasive power of the analysis in the context of the chapter.

The focus of the next core sampling chapter, "The Less Brave New World," is the increasingly close political relationship between security and migration that has emerged since the attacks of $9 / 11{ }^{28}$ Dauvergne argues that this relationship is born out of a phenomenon she calls "fact resistance," which is the tendency of nations and their citizens-in spite of evidence to the contrary-to find a correlation between increased refugee and migration flows and terrorist security threats. ${ }^{29} \mathrm{Her}$ core

\footnotetext{
23. Id, at 69 .

24. See id. at 71-74.

25. Id. at 80 .

26. $I d$.

27. Id at $80-81$.

28. Id. at 93 .

29. Id at 99-100.
} 
sample is the 2005 London subway bombings and subsequent government response. Despite the fact that British citizens planned and executed these attacks, the British government responded by cracking down on migrants and tightening border security. ${ }^{30}$ The logical disconnect in this response highlights Dauvergne's broader point regarding the irrationality of the migration-security matrix: the more that security threats fail to match up to the "us-them" division reinforced by migration law and border security, the more Western nation-states attempt to reassert the sovereign control afforded them through domestic migration law. ${ }^{31}$

Dauvergne's analysis of state responses to security threats, including the pressure placed on the rule of law by the more severe examples of these responses, is sharp and convincing. Her focus on the British crackdown on migrants following the terror attacks is especially effective at uncovering the underlying irrationality of political security decision-making. This chapter serves as an example of the persuasive power of Dauvergne's core sampling strategy, leading the reader to draw broad conclusions from well-chosen narrow instances.

Dauvergne next turns her attention to citizenship law and the role it plays in combination with migration law in creating and maintaining national borders. Dauvergne argues that this relationship, which she terms the citizenship law-migration law dichotomy, allows liberal Western states to maintain citizenship laws that on their face promote equality and tolerance, while still pursuing economically motivated immigrant selection through the enforcement of domestic migration laws. ${ }^{32}$ Such selection, she claims, is often highly gendered, as it selects for economic factors that favor men over women and casts migrant women in a role of dependence. ${ }^{33}$ The basic logic of Dauvergne's position is simple to follow. Prosperous Western states that are popular destinations for migration have been able to expand the benefits and relax the requirements of their citizenship laws by making the standards for first obtaining permanent residency more onerous. ${ }^{34}$ In so doing, the state reduces the population of those eligible for citizenship, allowing the state to keep the language of its citizenship law consistent with traditional, liberal tolerance. ${ }^{35}$

30. Id. at 102 .

31. See id. at 116 .

32. See id. at $121-24$ (stating that "[i]n prosperous Western nations with developed immigration programs, migration law rather than citizenship law is the principal effective hurdle to formal membership" and that "[c]itizenship law perfects the exclusionary mechanism of migration law by cloaking it in a discourse of inclusion").

33. Id. at 126-28.

34. Id. at 122 .

35. See id. at 123 . 
This chapter is yet another example of the persuasive power of the structure of Dauvergne's approach. The central assertion of her argument here is an impeachment of the motives of powerful Western states in crafting contradictory and hypocritical laws governing the makeup of their populations, and Dauvergne marshals evidence and presents observations in such a way as to make the conclusion seem unavoidable. Of course, one obvious critique of Dauvergne's core sampling strategy is that, by selectively presenting isolated pockets of evidence, she is rigging her argument to have just such an effect. But Dauvergne is careful to avoid generalizations and keep her arguments grounded in her specific examples. She never allows the reader to forget that her project is one of selective sampling, but her arguments still feel convincing and broadly intuitive.

Finally, Dauvergne focuses on the effects that two major global powers-the United States and the European Union-have had on migration policy in the era of globalization. ${ }^{36}$ She argues that, although the European Union is often seen as a beacon of a hopeful future without borders and the United States is often critiqued as a superpower intent on ensuring that globalization resembles Americanization, the two have much in common when it comes to migration law and policy. ${ }^{37}$ After reviewing a number of recent policy changes in the European Union and their results, Dauvergne concludes that E.U. efforts to harmonize the domestic migration laws of member states are reflective not of a desire to make these laws more inclusive and equitable, but rather to more effectively exclude undesirables. ${ }^{38}$ Next, Dauvergne examines the most recent social and political turmoil stemming from the instability of the U.S.-Mexico border. She concludes that, although disputes over the security of this border have existed for more than a century, the pressures of globalization have shifted the nature of the debate, turning what used to be little more than a cyclical, low-priority campaign issue into an intensified, surveillance-heavy border enforcement call to arms. ${ }^{39}$ The U.S. response to these pressures, Dauvergne argues, demonstrates the increased desire of nation-states to close their borders to illegal migrants and their increasing inability to do so within the confines of liberalism and the rule of law. ${ }^{40}$

In her discussion of the U.S.-Mexico border, Dauvergne makes an interesting and complicated observation about the role that vigilantism

\footnotetext{
36. Id. at 142 .

37. Id. at 162 .

38. Id. at 154 .

39. Id at 156 .

40. See id. at 162-63.
} 
has begun to play in the enforcement of domestic immigration laws. ${ }^{41}$ The role of private vigilante patrol groups in the migration debate can be interpreted as a sign of the spread of the forces of globalization, but it can just as easily be seen as a pocket of resistance to these forces. ${ }^{42}$ The shift of power from nation to private entity is a traditional characteristic of a globalizing world, and vigilantes who enforce their interpretation of domestic law certainly fit this pattern. But Dauvergne suggests that vigilantism can also be seen as a distinctly U.S. form of resistance to the outside pressures of globalization. ${ }^{43}$ The fact that this resistance is being offered by private actors who see themselves as filling a gap in government enforcement of domestic migration law is yet another indication that globalization threatens state control over policy and that migration law may be the last battleground for nation-states in their attempt to reassert sovereignty.

Dauvergne's central argument throughout her book-that domestic migration law is the last bastion of sovereignty available to Western states besieged by the forces of globalization-is well-served by her strategy of selectively core sampling the relevant areas of policy and law. While this approach brings with it the danger of occasional divergences from the central logical thread of the argument (as Dauvergne's protracted, if interesting, discussion of the photographs in the TIP Report illustrates), the author is largely able to avoid such distractions. Despite a few tangents, the benefits of Dauvergne's strategy far outweigh any drawbacks it presents. In the interest of brevity, I have been forced to omit many of the nuances and, in some cases, major aspects of Dauvergne's arguments. This Review should by no means serve as a substitute for reading her book, which is highly recommended for those interested in the convergence of migration law, globalization, and sovereignty.

41. Id. at 160 .

42. Id.

43. Id 